\title{
Pollen morphology of Waltheria L. (Malvaceae-Byttnerioideae) from Bahia, Brazil
}

\section{Cristiano Eduardo Amaral Silveira Júnior ${ }^{1,3^{*}}$, Luciene Cristina Lima e Lima ${ }^{1,2}$ and Marileide Dias Saba ${ }^{1,3}$}

Received: April 27, 2017

Accepted: May 29, 2017

\begin{abstract}
Waltheria encompasses about 60 species distributed in Brazil and Mexico. To improve the palynology of the genus, we analyzed 14 species occurring in the Brazilian State of Bahia. Pollen grains were acetolyzed and examined using light microscopy and scanning electron microscopy. Non-acetolyzed pollen grains were viewed by transmission electron microscopy. The results revealed two general pollen types based on exine ornamentation, such as reticulate and echinate, which are distinct with regard to (1) size and shape, (2) apertural type and number, (3) relative length of ectoapertures, and (4) thickening of the nexine compared to the sexine. An ultrastructural analysis of the pollen wall revealed a continuous foot layer and a compact and discontinuous endexine in most cases. The sexine consisted of heterogeneous columellae, which support a perforated semitectum (echinate type) or the semitectum was composed of perforations and muri-shaped thickening (reticulate type). These results confirm a high degree of pollen dimorphism in Waltheria associated with heterostyly.
\end{abstract}

Keywords: heterostyly, palynology, ultrastructure, taxonomy, Waltheria

\section{Introduction}

Waltheria (Malvaceae - Byttnerioideae) is a primarily neotropical genus, composed of mostly shrubs and subshrubs that bloom for several months during the year. It is distributed in two major centers of diversity, such as Brazil and Mexico, and encompasses about 60 species, of which 21 occur in Brazil, including 13 endemic species (Saunders 1993; Esteves 2015). Waltheria is characterized morphologically by a unicarpellate gynoecium (Schumann 1886), and the genus is divided into three subgenera (Waltheria, Pringley and Virgata) and two sections Waltheria and Stegowaltheria, based on the type of fruit dehiscence, stipule and seed testa morphology, and type of trichome (Schumann 1886; Saunders 1995).
According to Saunders (1993), approximately 50 Waltheria species are distylous, a type of heterostyly in which two mating types in a species differ in floral morphology, with regards to stamen and style length. Stamens are shorter than styles in longistylous morphs, whereas brevistylous morph styles are shorter than stamens. This floral heteromorphism is genetically controlled, and the reciprocal length of the gynoecium and androecium in longistylous and brevistylous flowers favors cross-fertilization between them, considering that most species are self-incompatible (Ganders 1979).

An extraordinary pollen dimorphism associated with this floral heteromorphism has evolved within the genus, as longistylous and brevistylous morphs produce reticulate and echinate pollen grains, respectively. The differences go beyond the features of the exine and include the size and shape of the pollen and the number and shape of the

\footnotetext{
${ }^{1}$ Programa de Pós-Graduação em Biodiversidade Vegetal, Departamento de Educação, Universidade do Estado da Bahia, Campus VIII, 48608-240, Paulo Afonso, BA, Brazil

${ }^{2}$ Laboratório de Estudos Palinológicos, Universidade do Estado da Bahia, Departamento de Ciências Exatas e da Terra, Campus II, 48000-000, Alagoinhas, BA, Brazil

${ }^{3}$ Laboratório de Estudos Palinológicos, Universidade do Estado da Bahia, Departamento de Educação, Campus VII, 48970-000, Senhor do Bonfim, BA, Brazil

* Corresponding author: silveirajunior_cea@yahoo.com.br
} 


\section{Cristiano Eduardo Amaral Silveira Júnior, Luciene Cristina Lima e Lima and Marileide Dias Saba}

apertures (Köhler 1971; 1973; 1976; Melhem et al. 1976; Saunders 1993; 1995; 2005; Saba \& Santos 2000; 2003; 2015; Saba et al. 2004). This degree of heteromorphism in Malvaceae is also observed in the genus Melochia, reflecting the close relationship of these taxa in the family (SilveiraJúnior et al. 2015).

Although heterostyly was recognized in early studies by Darwin (1877) and was observed in the genus Waltheria in the same century by Schumann (1886), the existing pollen dimorphism has not been studied by other authors. Only isolated species have been analyzed, and the pollen grains of brevistylous and longistylous morphs have not been compared (e.g. Erdtman 1952; Sharma 1970; Melhem et al. 1976; Palacios-Chávez et al. 1990; Roubik \& Moreno 1991; Miranda et al. 1992; Saba \& Santos 2003).

The most important palynological studies of Waltheria, which have provided detailed views of pollen grains under scanning electron microscopy (SEM) include Köhler (1971; 1976), Saunders (1993; 1995), Saba et al. (2004) and Saba \& Santos (2015). These are the only authors who observed stratification of the pollen exine in Waltheria under transmission electron microscopy (TEM).

This study characterized the pollen morphology of heterostylous Waltheria species known in the flora of the Brazilian State of Bahia and verified the quantitative and qualitative differences in their pollen grains to provide taxonomic data of the genus.

\section{Materials and methods}

We selected 14 Waltheria species listed as occurring in the State of Bahia (Saunders 1995; Esteves 2015) from the CEPEC, HUEFS, SP, and SPF herbaria (acronyms according to Thiers, 2014). When possible, the specimens used were those that had been determined by experts as belonging to the genus. The pollen grains were collected from three specimens of each taxon that contained the floral morphs previously examined by the authors. Due to a lack of material, some material from other states was examined.

\section{Examined material}

Waltheria ackermanniana K. Schum: Brazil. Bahia: Rio de Contas, 20/I/1984, Hatschbach G. 47381 (CEPEC); Morro do Chapéu, 15/III/1990, Saunders J. 3105 (CEPEC); Morro do Chapéu, 15/III/1990, Saunders J. \& Carvalho A. M. 3107 (CEPEC). W. albicans Turcz.: Brazil. Bahia: Brumado, 21/ III/1990, Saunders J. \& Carvalho A. M. 3149 (CEPEC); Bahia: Casa Nova, 16/VI/2001, Nunes T. S. et al. 520 (HUEFS); Bahia: Morro do Chapéu, 16/III/1990, Saunders J. \& Carvalho A. M. 3117 (CEPEC). W. brachypetala Turcz: Brasil. Bahia: Morro do Chapéu, 16/III/1990, Saunders J. \& Carvalho A. M. 3116 (CEPEC); Bahia: Lençóis, 17/III/1990, Saunders J. \& Carvalho A. M. 3119 (CEPEC); Bahia: Canudos, 24/X/2001, Queiroz L. P. 7010 (HUEFS). W. bracteosa A. St.-Hil. \&
Naudin: Brazil. Bahia: Mucugê, 20/III/1990, Saunders J. \& Carvalho A. M. 3143 (CEPEC); Bahia: Gentio do Ouro, 26/II/1977, Harley R. M. 19119 (CEPEC). W. cinerascens A. St.-Hil.: Brazil. Bahia: Canavieiras, 11/III/1990, Saunders J. \& Carvalho A. M. 3222-B (CEPEC); Bahia: Valença, 11/ XII/1980, Matos-Silva L. A. et al. 1252 (CEPEC); Bahia: Andaraí, 20/V/1989, Matos-Silva L. A. et al. 2819 (CEPEC). W. communis A. St.-Hil.: Brazil. Bahia: Porto Seguro, 01/V/1990, Saunders J. \& Carvalho A. M. 3227-A (CEPEC); Bahia: Porto Seguro, 01/V/1990, Saunders J. \& Carvalho A. M. 3229 (CEPEC); Bahia: Senhor do Bonfim, 27/III/2004, Giulietti A. M. 2455 (HUEFS). W. coriacea J. G. Saunders: Brazil, Bahia: Formosa do Rio Preto, 28/III/2000, Harley R. M. 53757 (CEPEC); Bahia: Formosa do Rio Preto, 03/IV/2000, Oliveira R. P. 467 (HUEFS). W. excelsa Turcz.: Brazil, Bahia: Maracajú, 17/III/1990, Saunders J. \& Carvalho A. M. 3122 (CEPEC). W. macropoda Turcz.: Brazil. Bahia: Xique-xique, 17/III/1990, Saunders J. \& Carvalho A. M. 3123 (CEPEC); Bahia: Oliveira dos Brejinhos, 16/IV/1999, Sant'Ana S. C. et al. 778 (CEPEC); Pernambuco: Orocó, 27/IV/2001, Harley R. M. et al. 54313 (CEPEC) W. operculata Rose: Brazil. Bahia: São Inácio, 25/II/1977, Harley R. M. 19024 (SPF); W. rotundifolia C. Presl.: Brazil. Bahia: Maracajú, 18/III/1990, Saunders J. \& Carvalho A. M. 3126 (CEPEC); Bahia: Paulo Afonso, 18/V/1981, Gonçalves L. M. C. 76 (CEPEC). W. selloana K. Schum.: Brazil. Bahia: Rio de Contas, 13/VII/1985, Kral R. et al. 72731 (CEPEC); Bahia: Rio de Contas, 21/VII/1979, Mori S. A. et al. 12379 (CEPEC). W. vernonioides R. E. Fr.: Brazil. Mato Grosso: Cuiabá, no date, Hoehne E. C. 2976 (SP); Goiás: Monte Alegre de Goiás, 22/II/1990, Saunders J. et al. 3060 (CEPEC). W. viscosissima A. St.-Hil.: Brazil. Bahia: Santa Luzia, 01/V/1990, Saunders J. \& Carvalho A. M. 3234 (CEPEC); Bahia: Lençóis, 02/VII/2001, Roque N. et al. 533 (CEPEC); Bahia: Feira de Santana, Noblick L. R. et al. 2359 (CEPEC).

Pollen grains for light microscopy (LM) were taken from two or three flowers per sample and were prepared using the acetolysis protocol (Erdtman 1960). The slides were mounted and deposited in the Palynology Laboratory of the Universidade do Estado da Bahia, Campus VII.

The major morphometric parameters (equatorial and polar diameters) were measured on 25 pollen grains, and the aperture diameters and exine, sexine and nexine thicknesses were measured in ten randomly chosen pollen grains. The arithmetic average, standard deviation, standard deviation of the average, coefficient of variation, and $95 \%$ confidence intervals were calculated for the statistical analysis.

The pollen surface was analyzed by SEM (JEOL 6390LV; Tokyo Japan) at the Electron Microscopy Platform of Centro de Pesquisas Gonçalo Moniz-FIOCRUZ. The pollen grains were acetolyzed, washed, and dehydrated in an ascending hydroethanol series (50, 70, 90, and $100 \%)$ for about 10 min in each phase. Absolute alcohol containing the pollen grains was dripped directly over SEM stubs (in a specimen holder), which were metallized by gold evaporation in a high vacuum after they dried completely. 


\section{Pollen morphology of Waltheria L. (Malvaceae-Byttnerioideae) \\ from Bahia, Brazil}

The TEM analysis was carried out at FIOCRUZ using a Zeiss EM 109 microscope (Zena, Germany). The chemical treatment of the samples followed the protocol used by Silveira-Júnior et al. (2015). Briefly, non-acetolyzed pollen grains were fixed in glutaraldehyde ( $2.5 \%)$ in $0.1 \mathrm{M}$ sodium cacodylate buffer solution, washed in a sodium cacodylate buffer solution and post-fixed in osmium tetroxide (1\%), potassium ferricyanide $(0.8 \%)$, and $5 \mathrm{mM}$ calcium chloride in sodium cacodylate buffer. The pollen grains were washed again and dehydrated in an ascending acetone series (30,50, $70,90$, and $100 \%)$. The samples were embedded in Epon resin, the blocks were cut at $70 \mathrm{~nm}$ on an ultramicrotome (Ultracut E), and contrasted in uranyl acetate (7\%) and lead citrate.

All material was illustrated by photomicrographs and scanning and transmission electromicrographs. We adopted the palynological terminology used by Punt et al. (2007) and Hesse et al. (2009) to describe the pollen characters.

\section{Results}

The pollen grains are shown in the Figures $1-8$. The morphological characteristics are summarized in Tables 1 and 2, and the morphometric data are shown in Tables 3 and 4 . The species was grouped into reticulate and echinate types based on exine ornamentation. The apertural type, number, and distribution allowed grouping the species into three (reticulate pollen grains) and four (echinate) categories (Fig. 8).

\section{Reticulate type}

The longistylous and homostylous (W. operculata) specimens characterized the reticulate type of pollen grain: mostly medium to large; isopolar or apolar only in $W$. communis and $W$. rotundifolia; oblate spheroidal, prolate spheroidal and spherical (apolar pollen grains); amb circular, subcircular, rarely quadrangular (W. coriacea, Fig. 2 I) and polygonal; zonocolporate and pantocolporate (W. communis and $W$. rotundifolia).

The ectoapertures are long to short, often narrow, with a generally regular outline, without a margin, with tapered ends less often rounded (Figs. 1F, J, M, 2B, F, J, 3B, F, M). The ectoapertures are difficult to identify and measure in $W$. communis and $W$. rotundifolia, and they barely extend to the limits of the endoapertures.

The endoapertures are lolongate in Waltheria bracteosa (Fig. 1M), circular in W. communis (Fig. 2E) and W. rotundifolia (Fig. 3G), or lalongate in the other species, showing variations in relation to height and width between species. The inferior and superior margins of the endoapertures are frequently concave and elliptical in shape. A slight constriction in the middle of both margins may occur in W. albicans (Fig. 1F) and the lateral margins, when visible, are rounded or elliptical. A costa and fastigium are present in almost all species, except in $W$. communis and $W$. rotundifolia.
The sexine is often thicker than the nexine (Tabs. 3, 4); a thinner sexine occurs in $W$. brachypetala (Fig. $1 \mathrm{~J}$ ) and is of equal thickness in $W$. bracteosa. Under ML, the reticula have irregular lumina and are usually heterogeneous with respect to size (Figs. 2F, 3E). Homogeneous lumina occurred in pollen grains of $W$. ackermanniana and $W$. bracteosa and a circular form occurred only in $W$. ackermanniana. The lumina are typically $\geq 1 \mu \mathrm{m}$ in diameter. The walls are simplicolumellate, continuous, and straight.

The columellae are distinct in optically sectioned and SEM images, alternating between larger and smaller, maintaining an undulating or slight undulating semitectum (Figs. 1F, 3F-G, 4E', M'); however, no undulation was observed in W. coriacea (Fig. 2I). SEM also revealed perforations on the muri of $W$. ackermanniana, W. albicans, W. brachypetala, $W$. communis, and $W$. rotundifolia pollen grains (Figs. 4B, E, G, 5B, M). Furthermore, the lumina possessed perforations in most species.

The ultrastructure of the pollen grain wall revealed a distinct nexine in a continuous foot layer and a discontinuous and compact endexine (Fig. 7A-H). The foot layer is generally thinner than the endexine; however, both have the same thickness in $W$. operculata (Fig. 7G). The sexine is formed by thin and heterogeneous columellae with respect to size. The columellae in $W$. ackermanniana is short at the apertural region where there is a thickening of the nexine (costa, Fig. 7B). The columellae are uniformly distributed in W. ackermanniana (Fig. 7A), although they are further apart in $W$. operculata. The columellae in $W$. ackermanniana and $W$. operculata support a relatively thick semitectum with internal foramina and sparse or densely distributed perforations in W. macropoda (Fig. 7E). Muri shaped thickening on the semitectum was observed in all samples. A thick and continuous intine was observed only in W. macropoda.

\section{Echinate type}

The echinate type characterized pollen grains of the brevistylous specimens and homostylous specimens of $W$. selloana and $W$. vernonioides: medium or mostly large pollen grains; isopolar, but apolar in W. communis, W. rotundifolia, and $W$. vernonioides; suboblate, oblate spheroidal (most species), and spherical (apolar pollen grains); amb circular and polygonal; 5-8 zonocolporate or less often 10-14 pantobrevicolporate ( $W$. rotundifolia) and 10-16 pantopororate (W. communis and W. vernonioides).

The ectoapertures are long or short, slightly wide, and circular in W. communis (Fig. $2 \mathrm{H}$ ) and $W$. vernonioides (Fig. $3 \mathrm{~K})$. The outline of the ectoaperture is often irregular or not clearly visible in $W$. ackermanniana (Fig. 1D) and W. albicans (Fig. 1H). The ectoapertures in W. rotundifolia are difficult to identify and measure due to the slightly stretched limits of the endoaperture (brevicolporus). The apertural membrane may present with ornamented echinae, as in $W$. coriacea (Fig. 2L) and W. selloana (Fig. 3I). The ectoapertures have 
Cristiano Eduardo Amaral Silveira Júnior, Luciene Cristina Lima e Lima and Marileide Dias Saba
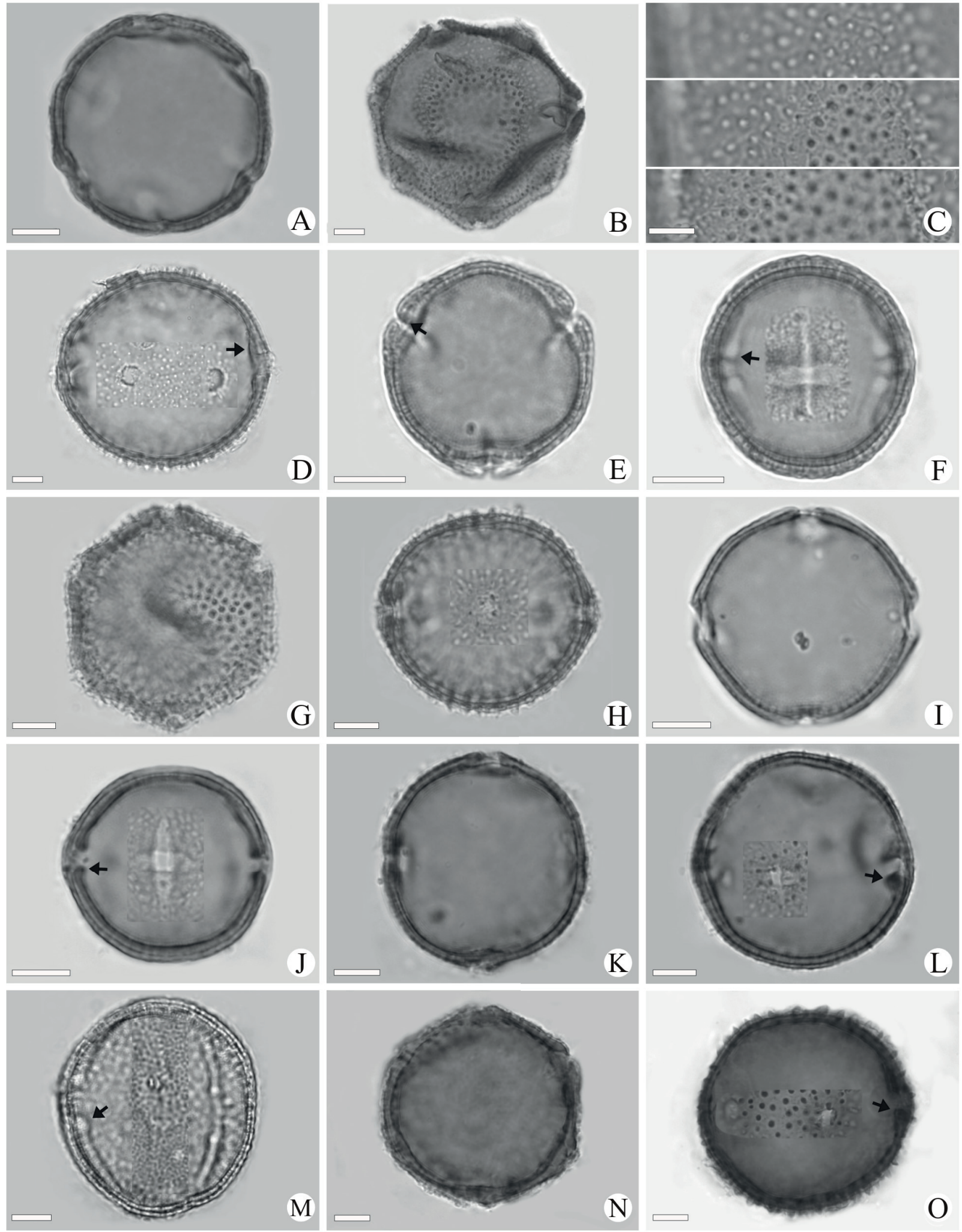

Figure 1. Light micrographs of Waltheria L. pollen grains. Waltheria ackermanniana (Reticulate): A. Polar view; W. ackermanniana (Echinate): B. Polar view; C. LO Analysis; D. Equatoial view, costa detail (arrow). W. albicans (Reticulate): E. Polar view, fastigium detail (arrow); F. equatorial view, costa detail (arrow); W. albicans (Echinate): G. Polar view; H. Equatorial view. W. brachypetala (Reticulate): I. Polar view; J. Equatorial view, costa detail (arrow); W. brachypetala (Echinate): K. Polar view; L. Equatorial view, costa detail (arrow). W. bracteosa (Reticulate): M. Equatorial view, costa detail (arrow); W. bracteosa (Echinate): N. Polar view; O. Equatorial view, costa detail (arrow). Scales bar $=10 \mu \mathrm{m}$. 


\section{Pollen morphology of Waltheria L. (Malvaceae-Byttnerioideae) from Bahia, Brazil}
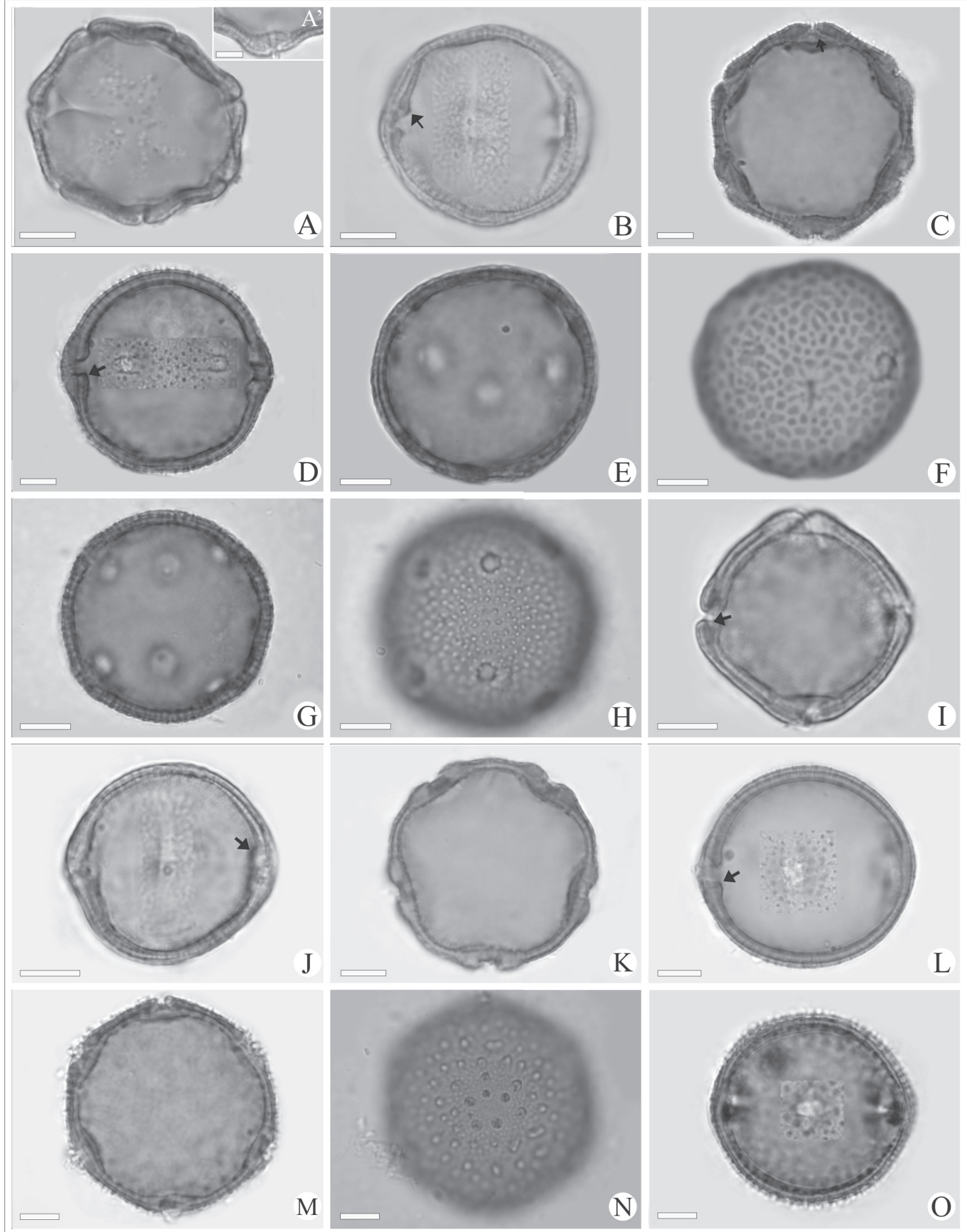

$\mathrm{K}$

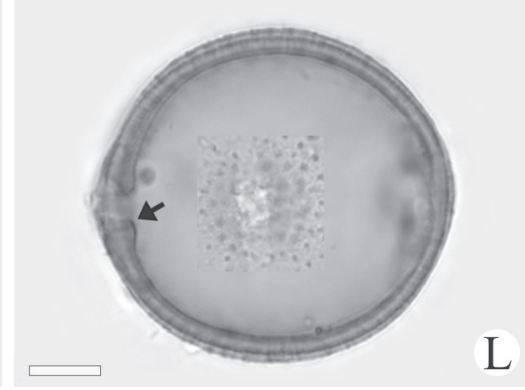

$\mathrm{N}$

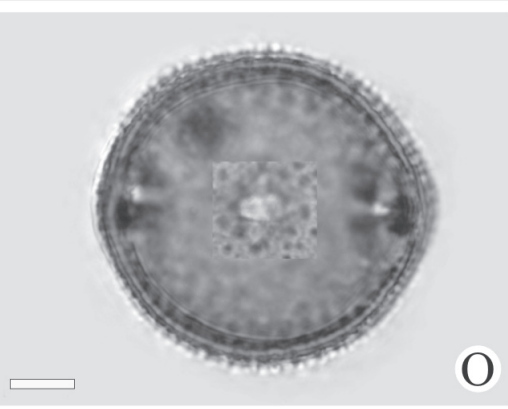

Figure 2. Light micrographs of Waltheria L. pollen grains. W. cinerascens (Reticulate): A. Polar view; A'. Fastigium detail; B. Equatorial view, costa detail (arrow). W. cinerascens (Echinate): C. Polar view, fastigium detail (arrow); D. Equatorial view, costa detail (polar view). W. communis (Reticulate): E. Polar view, optical section; F. Polar view, surface. W. communis (Echinate): G. Polar view, optical section; H. Polar view, surface. W. coriacea (Reticulate): I. Polar view, fastigium detail (arrow); J. Equatorial view, costa detail (arrow). W. coriacea (Echinate): K. Polar view; L. Equatorial view, costa detail. W. excelsa (Echinate): M. Polar view, optical section; N. Polar view, surface; O. Equatorial view. Scales bar: $\mathrm{A}^{\prime}=5 \mu \mathrm{m}$; other figures $=10 \mu \mathrm{m}$. 


\section{Cristiano Eduardo Amaral Silveira Júnior, Luciene Cristina Lima e Lima and Marileide Dias Saba}
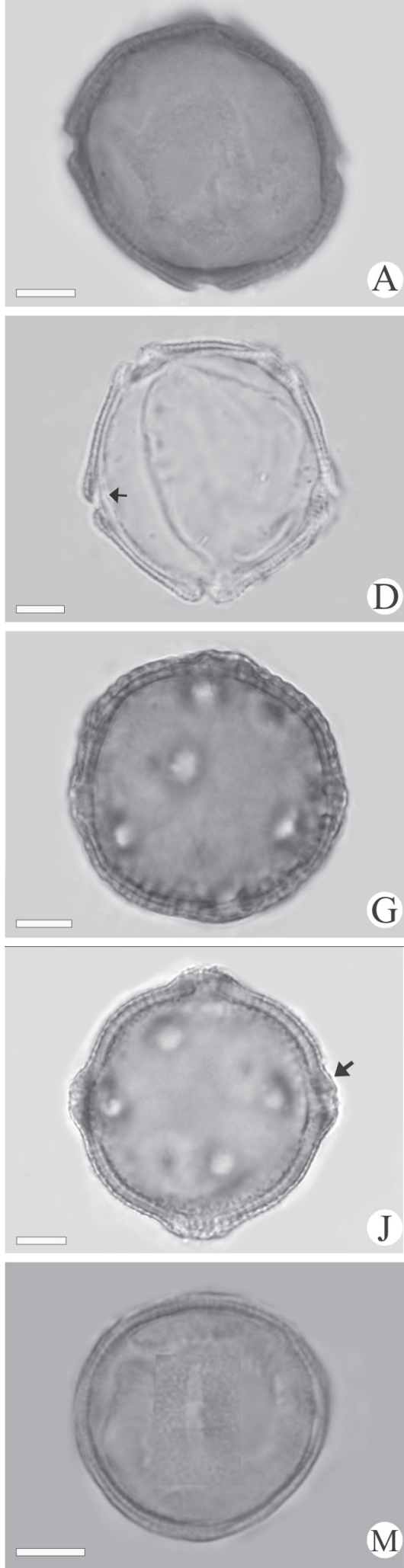

D
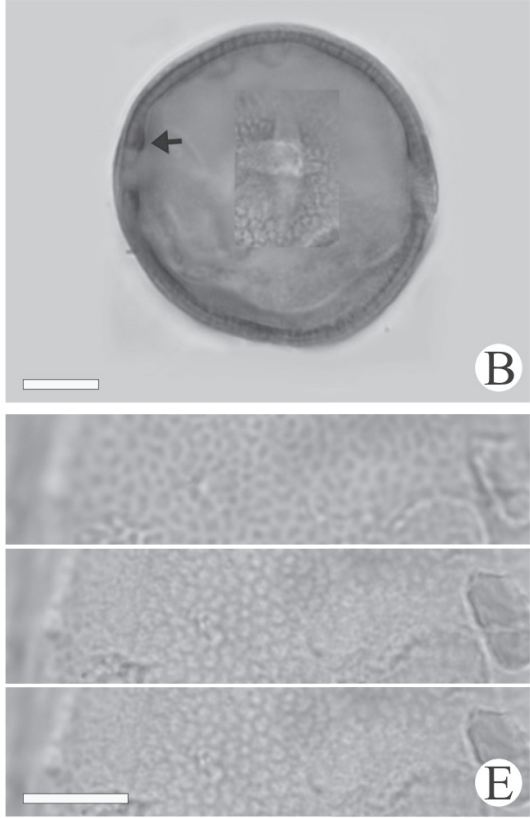

E

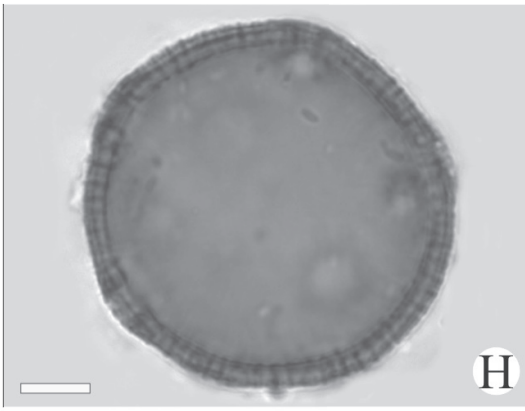

$\mathrm{H}$

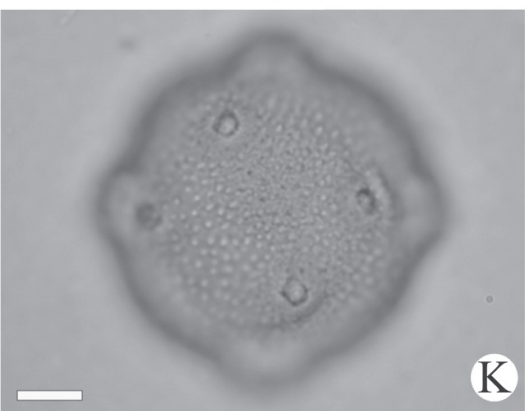

K

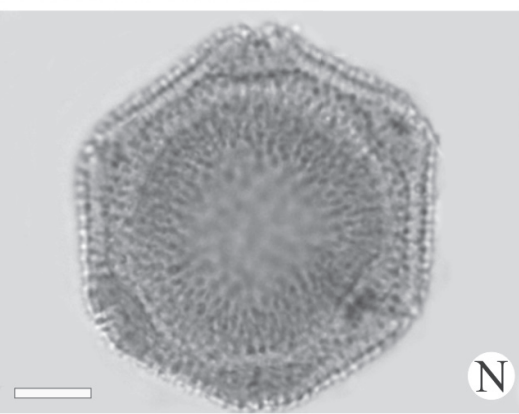

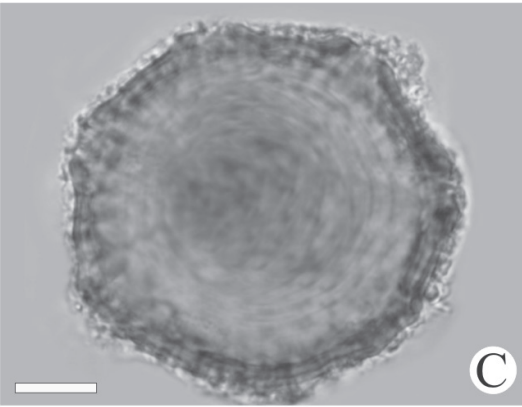

C
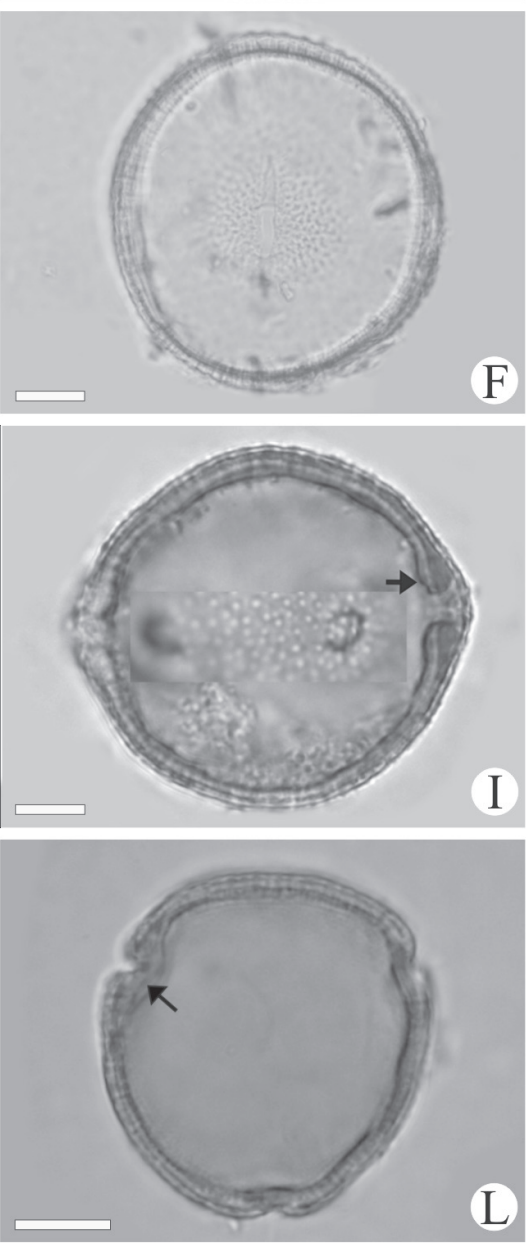

L

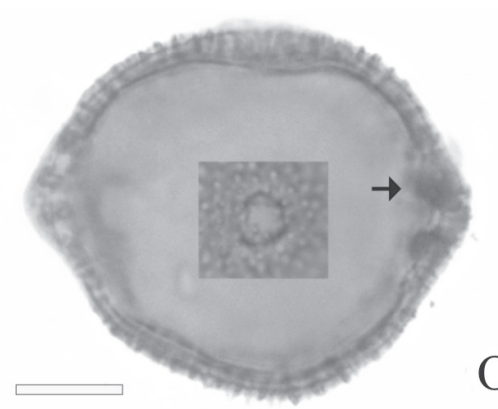

Figure 3. Light micrographs of Waltheria L. pollen grains. W. macropoda (Reticulate): A. Polar view; B. Equatorial view, costa detail (arrow). W. macropoda (Echinate): C. Polar view. W. operculata (Reticulate): D. Polar view, fastigium detail (arrow); E. LO Analysis; F. Equatorial view. W. rotundifolia (Reticulate): G. General view; W. rotundifolia (Echinate): H. General view. W. selloana (Echinate): I. Equatorial view, costa detail (arrow). W. vernonioides (Echinate): J. General view, aspis detail (arrow); K. General view, surface. W. viscosissima (Reticulate): L. Polar view, fastigium detail (arrow); M. Equatorial view; W. viscosissima (Echinate): N. Polar view; O. Equatorial view, costa detail (arrow). Scales bar $=10 \mu \mathrm{m}$. 

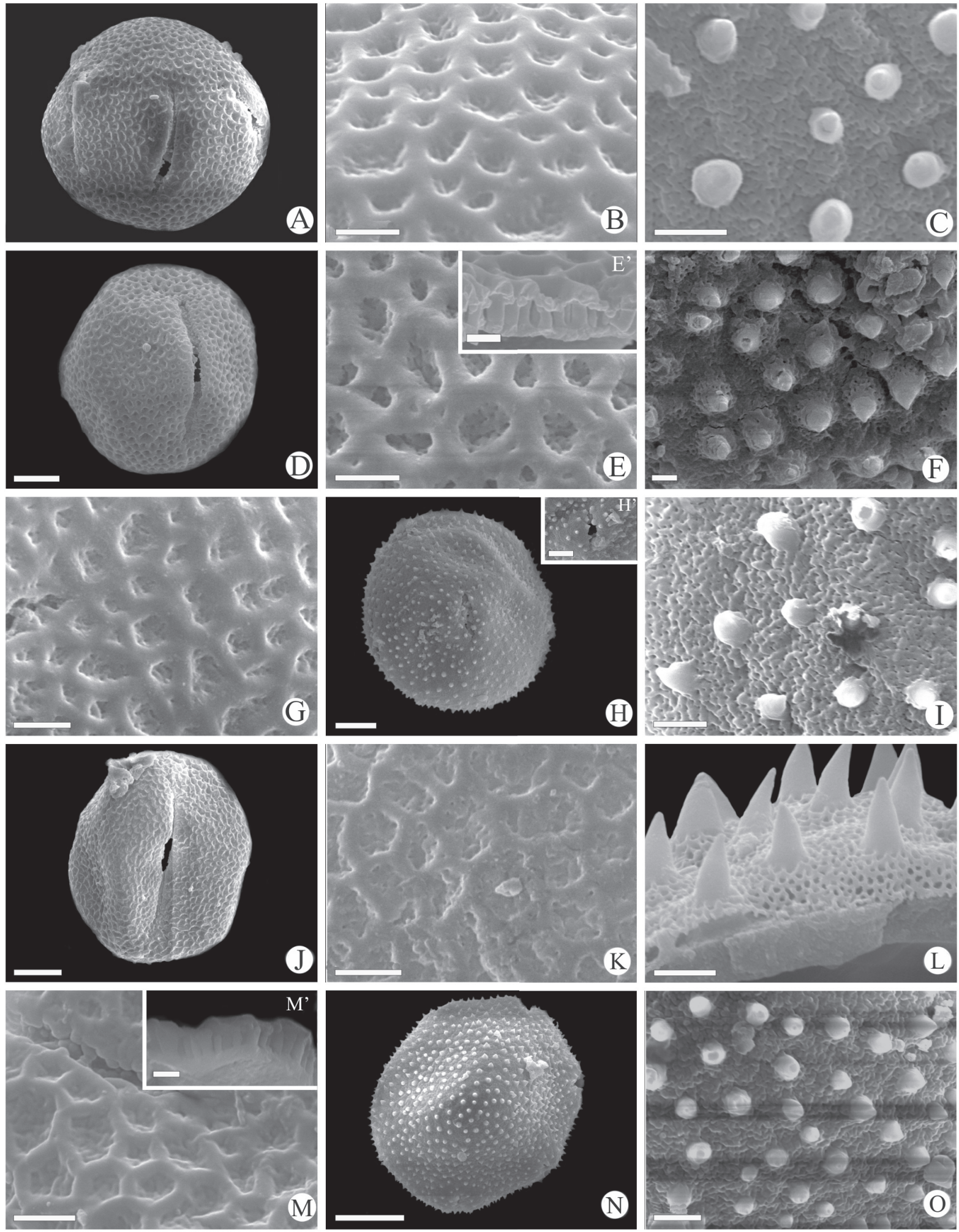

Figure 4. Scanning electron micrographs of Waltheria L. pollen grains. W. ackermanniana (Reticulate): A. Equatorial view; B. Exine ornamentation; W. ackermanniana (Echinate): C. Exine ornamentation. W. albicans (Reticulate): D. Equatorial view; E. Exine ornamentation; E'. Detail of the exine in a fragmented pollen grain. W. albicans (Echinate): F. Exine ornametation. W. brachypetala (Reticulate): G. Exine ornamentation. W. brachypetala (Echinate): H. Equatorial view; H'. Aperture detail; I. Exine ornamentation. W. bracteosa (Reticulate): J. Equatorial view; K. exine ornamentation. W. bracteosa (Echinate): L. Exine ornamentation. W. cinerascens (Reticulate): M. Exine ornamentation; M'. Detail of the exine in a fragmented pollen grain; $W$. cinerascens (Echinate): N. Polar view; O. Exine ornamentation. Scales bar: E', M' $=1 \mu \mathrm{m} ; \mathrm{B}, \mathrm{C}, \mathrm{E}, \mathrm{F}, \mathrm{G}, \mathrm{I}, \mathrm{K}, L, M, O=2 \mu \mathrm{m} . H^{\prime}=5 \mu \mathrm{m} A, D, H, J, N=10 \mu \mathrm{m}$. 
Cristiano Eduardo Amaral Silveira Júnior,

Luciene Cristina Lima e Lima and Marileide Dias Saba
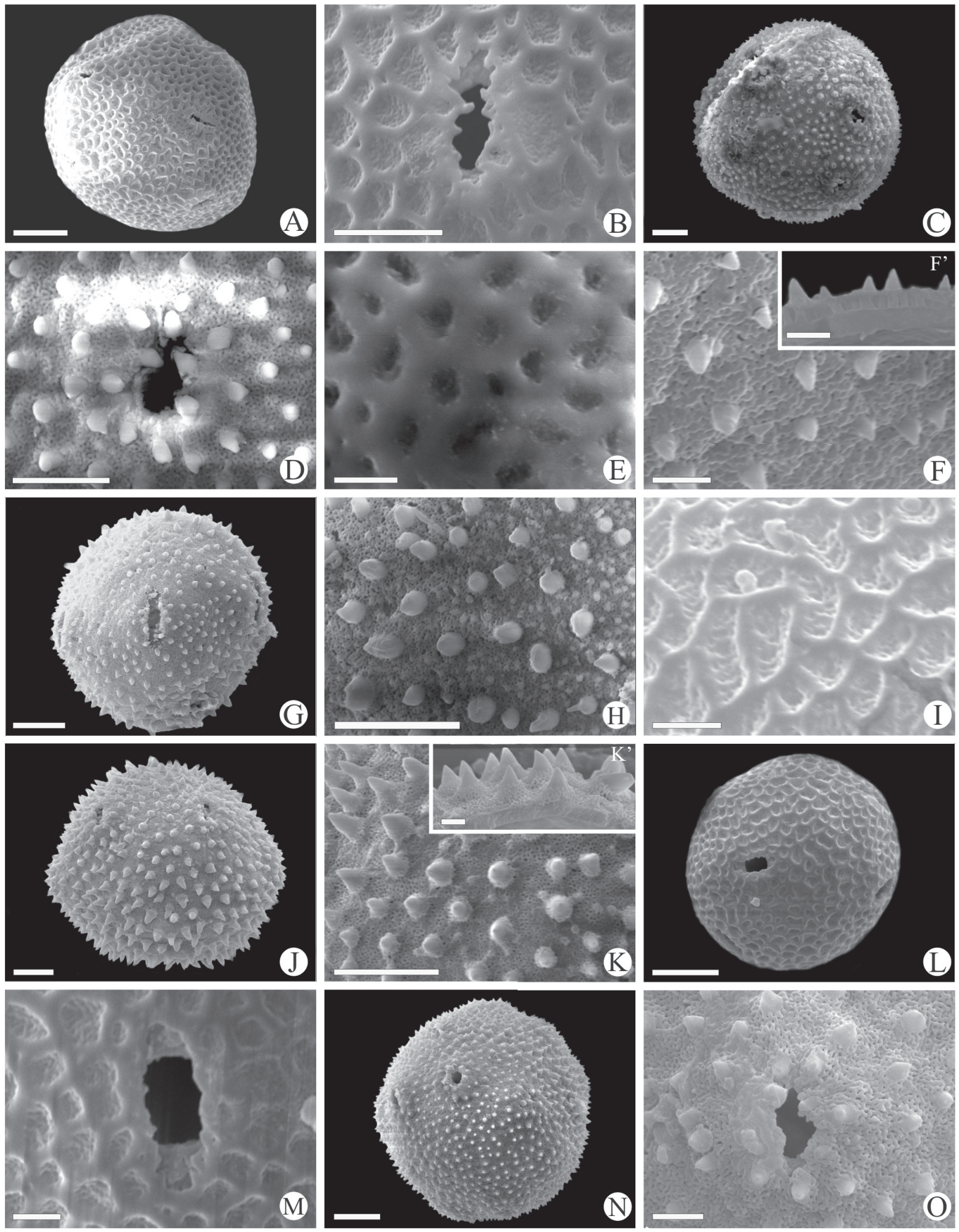

Figure 5. Scanning electron micrographs of Waltheria L. pollen grains. W. communis (Reticulate): A. General view; B. Exine ornamentation, aperture detail. W. communis (Echinate): C. General view; D. Exine ornamentation, aperture detail. W. coriacea (Reticulate): E. Exine ornamentation. W. coriacea (Echinate): F. Exine ornamentation; F'. Detail of the exine in a fragmented pollen grain. W. excelsa (Echinate): G. Equatorial view; H. Exine ornamentation. W. macropoda (Reticulate): I. Exine ornamentation; W. macropoda (Echinate): J. Equatorial view; K. Exine ornamentation; K'. Detail of the exine in a fragmented pollen grain. W. rotundifolia (Reticulate): L. General view; M. Exine ornamentation, aperture detail. W. rotundifolia (Echinate): N. General view; O. Exine ornamentation, aperture detail. Scales bar: E, F, F', I, K', M, O = $2 \mu \mathrm{m} ; B, D, H=5 \mu \mathrm{m} ; A, C, G, J, K, L, N=10 \mu \mathrm{m}$. 


\section{Pollen morphology of Waltheria L. (Malvaceae-Byttnerioideae) \\ from Bahia, Brazil}

tapered ends in almost all species, except they are rounded in $W$. excelsa (Fig. 2O).

The endoapertures are circular, lolongate in W. macropoda and $W$. rotundifolia and lalongate in most species. The latter may present superior and inferior concave (elliptical) or parallel (rectangular) margins (Figs. 1L, 2D, L, O, 3O). Both patterns occur in $W$. excelsa. W. communis and $W$. vernonioides have pollen grains with circular endoapertures (Figs. 2G$\mathrm{H}, 3 \mathrm{~J}-\mathrm{K})$, which are difficult to visualize, precluding their measurement and illustration under LM. Costae were observed in almost all species, whereas fastigia were only present in W. cinerascens (Fig. 2C). W. vernonioides was the only species to present pollen grains with aspides (Fig. $3 \mathrm{~J}$ ).

The nexine was thicker than the sexine in most cases; a thicker sexine was observed only in $W$. brachypetala, $W$. rotundifolia, and $W$. selloana. The supratectal elements are small and acute echinae, with a broad base, densely distributed throughout the surface of the pollen grain (Figs. 1C, 4H, L, N, 5C, F', G, H, J, K', N, 6A, B', D). The form of the echinae distribution varied slightly among species: they were located more distant from each other in W. brachypetala (Fig. 4H-I) and W. excelsa (Fig. 5G-H), while interspinal distance was about $1 \mu \mathrm{m}$ in $W$. rotundifolia, $W$. selloana, and $W$. vernonioides. Smaller echinae were observed in W. cinerascens (Fig. 4N) and the largest in W. macropoda (Fig. 5J-K').

The L.O. analysis revealed elevations in the tectum, similar to granules, smaller than echinae but also distributed over the surface of the pollen grain (Figs. 1C, 2N, 3K). The SEM analysis showed that these elevations are, in most species, the highest undulations on the semitectum wall. The presence of granules was confirmed only in W. excelsa pollen grains (Fig. $5 \mathrm{H}$ ).

The semitectum was one more element that differentiated some species under MEV, which may be either perforate in W. albicans (Fig. 4F), W. communis (Fig. 5D), W. selloana (Fig. $6 \mathrm{~B}$ ), and $W$. vernonioides (Fig. 6E); granulate-perforate in W. excelsa (Fig. 5H); microreticulate in W. bracteosa (Fig. 4L), W. macropoda (Fig. 5K), and W. viscosissima (Fig. 6F), or rugulate-perforate in $W$. ackermanniana (Fig. 4C), $W$. brachypetala (Fig. 4I), W. cinerascens (Fig. 4O), W. coriacea (Fig. 5F), and W. rotundifolia (Fig. 5O).

The walls of the echinate pollen grains were differentiated by a foot layer thicker than the compact and discontinuous endexine under TEM. The foot layer in W. macropoda is continuous and spongy in appearance (Fig. 7F). Furthermore, the wall has short and heterogeneous columellae, which are wider at the base of the echinae and have a densely perforated semitectum (Figs. 7D, F, H). W. brachypetala had a thick intine at the apertural region (Fig. 7D).

\section{Discussion}

The data presented here corroborate those found in the literature regarding pollen dimorphism among floral morphs of Waltheria L. Two distinct types of pollen grains have been observed in a single taxa (Köhler 1973; 1976;
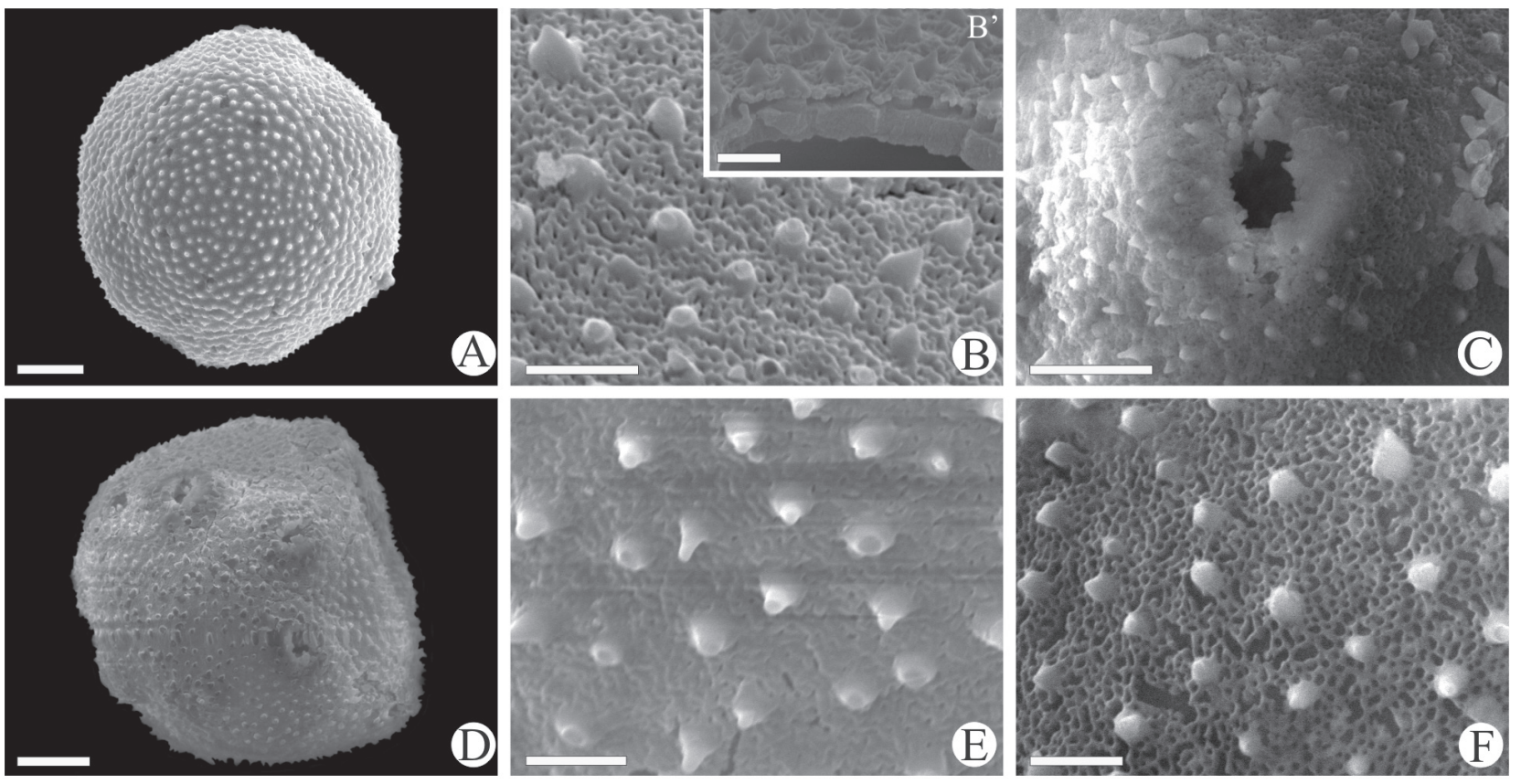

Figure 6. Scanning electron micrographs of Waltheria L. pollen grains. W. selloana (Echinate): A. Polar view; B. Exine ornamentation; B'. Detail of the exine in a fragmented pollen grain; C. Aperture detail. W. vernonioides (Echinate): D. General view; E. exine ornamentation. W. viscosissima (Echinate): F. Exine ornamentation. Scales bar: B, B', E, F = 2 $\mu \mathrm{m} ; C=5 \mu \mathrm{m} ; A, D=10 \mu \mathrm{m}$. 
Cristiano Eduardo Amaral Silveira Júnior, Luciene Cristina Lima e Lima and Marileide Dias Saba

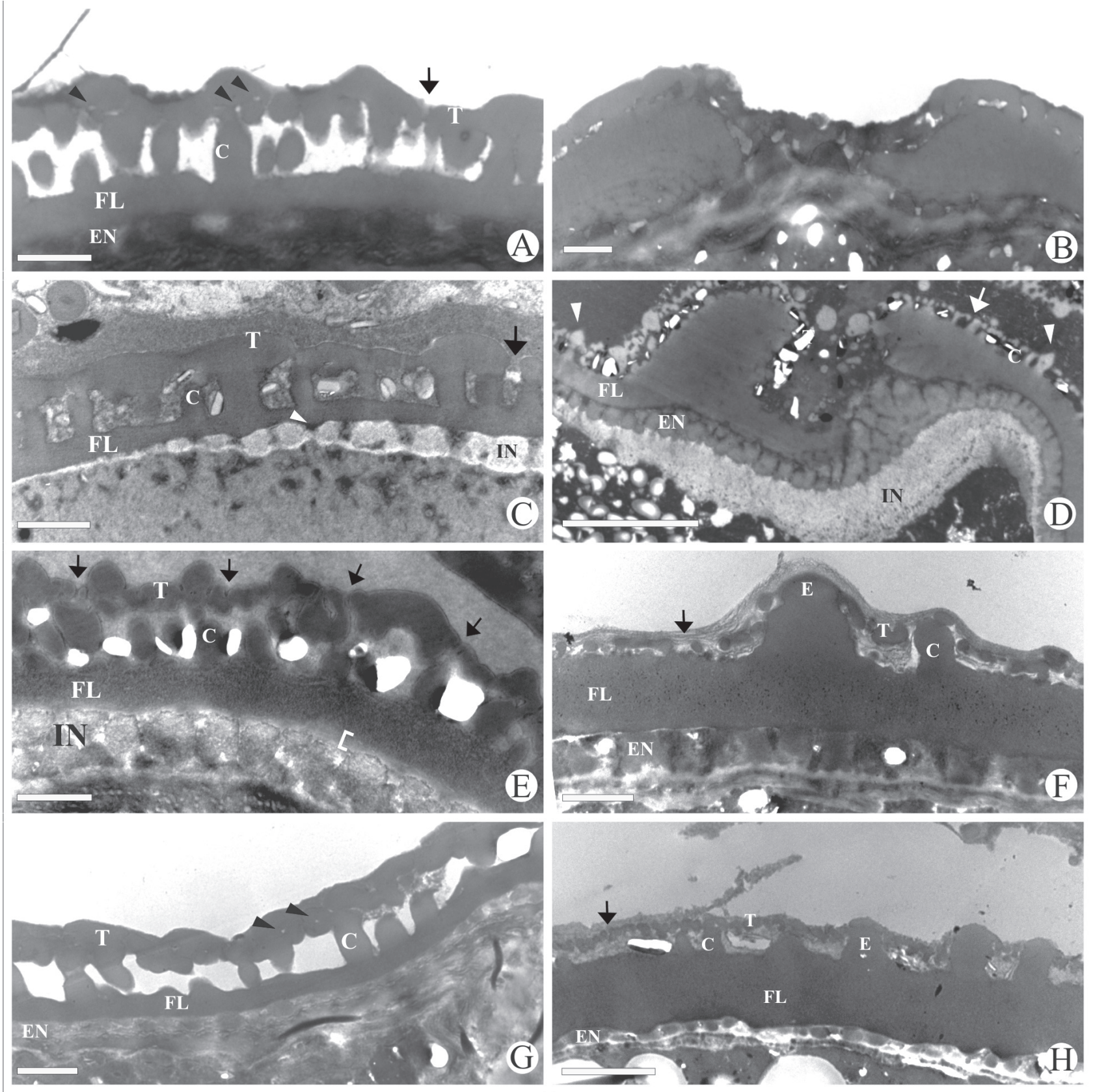

Figure 7. Trasmission electron micrographs of Waltheria L. pollen grains. W. ackermanniana (Reticulate): A. Wall structure showing internal foramina (arrowheads) and a perforation (arrow); B. Wall structure, apertural region. W. brachypetala (Reticulate): C. Wall structure showing endexine (arrowhead) and a perforation (arrow). W. brachypetala (Echinate): D. Wall structure on apertural region, showing perforation (arrow) and echinae (arrowhead). W. macropoda (Reticulate): E. Wall structure showing endexine (bracket) and a perforation (arrows). W. macropoda (Echinate): F. Wall structure showing perforation (arrow). W. operculata (Reticulate): G. Wall structure showing internal foramina (arrowheads). W. rotundifolia (Echinate): $\mathbf{H}$. Wall structure showing a perforation (arrow). (C= Columella; EN= Endexine; E= Echinus; FL=Foot Layer; IN= Intine; T= Tectum). Scales bar: D = $5 \mu \mathrm{m}$; other images $=1 \mu \mathrm{m}$.

Miranda \& Andrade 1989; Saunders 1993; 1995; Saba \& Santos 2000; 2003; Saba et al. 2004; Saunders 2005; Saba \& Santos 2015).

Brevistylous morphs always presented with larger pollen grains than those of the longistylous, which corroborated other studies (Köhler 1973; 1976; Miranda \& Andrade 1989;
Saunders 1993; 1995). Medium pollen grains prevailed among the reticulate type, while large ones prevailed among the echinate type. Saba et al. (2004) reported that mediumsized pollen grains are dominant among longistylous specimens, but they did not observe the prevalence of large pollen on the brevistylous morphs. 


\section{RETICULATE TYPE}

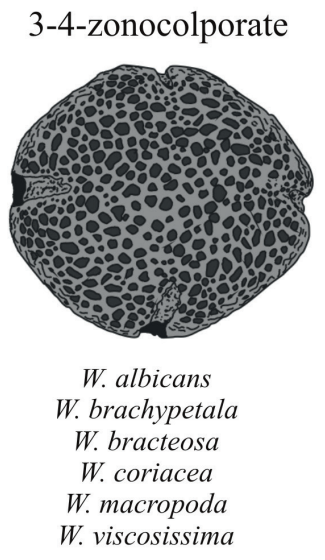

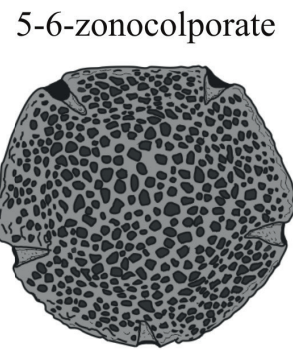

W. cinerascens

W. operculata

W. ackermanniana

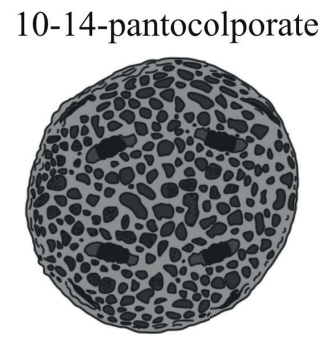

W. communis W. rotundifolia

\section{ECHINATE TYPE}
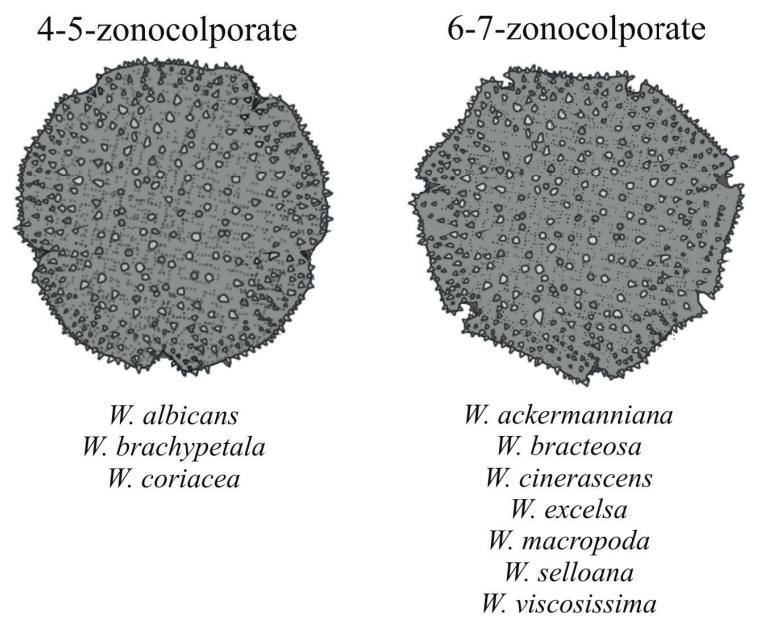

9-14-pantocolporate

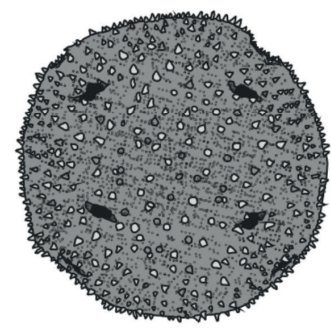

W. rotundifolia 10-16-pantoporate

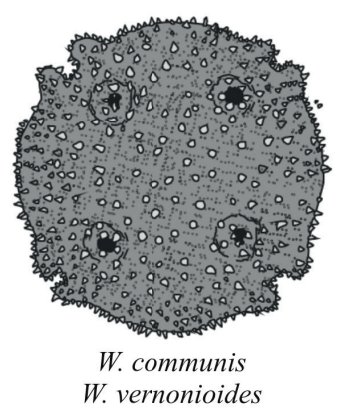

Figure 8. Grouping of the species relative to the apertural characteristics.

Echinate and reticulate pollen grains of Waltheria have a tendency to have prolate and oblate spheroidal shapes, respectively (Köhler 1971; 1973; Saba et al. 2004; Saba \& Santos 2015). According to Köhler (1976), this tendency is caused by the increase in the number of apertures in the echinate pollen grains.

The apolar pollen grains presented apertures arranged in a loop-like pattern, similar to the line on a tennis ball (Figs. 2E-H, 3G-H, J-K), a feature that can also be observed in Rubiaceae and Eriocaulaceae (Dessein et al. 2002; Dessein et al. 2005; Borges 2008). According to Dessein et al. (2005), these apertural types are intermediate forms between zono and genuine pantoaperturate grains.

Overall, echinate pollen grains had smaller ectoapertures than those of the reticulate type (Tabs 4,5 ). This has also been observed by other authors who have studied Waltheria (Köhler 1971; 1976; Miranda \& Andrade 1989; Saba \& Santos 2000; 2015; Saba et al. 2004).

The endoapertures of echinate pollen grains in most species were taller and smaller when compared with the reticulate type. These data corroborate, in part, the results reported by Köhler (1976), who observed only a smaller width of the endoapertures. Miranda \& Andrade (1989) described the same characteristics as the present study in specimens of $W$. viscosissima, which were also reported by Saunders (1993) for other species in the genus. Saba et al. (2004) found this same pattern in $W$. cinerascens and $W$. selloana, but only in the height of the endoapertures.

The number of apertures ranged from three to 14 on the reticulate pollen grains and from four to 16 on the echinate pollen. $W$. cinerascens and $W$. rotundifolia presented with the same number of apertures between the two floral morphs. The same results were found by Miranda \& Andrade (1989) and Saba et al. (2004) for W. brachypetala, W. cinerascens, and $W$. viscosissima.

The echinate pollen grains often had a thicker exine, but only $W$. rotundifolia had a thicker exine on its reticulate type pollen. Köhler $(1973 ; 1976)$ and Saunders (2005) reported 


\section{Cristiano Eduardo Amaral Silveira Júnior, Luciene Cristina Lima e Lima and Marileide Dias Saba}

Table 1. Morphological characteristics of Waltheria L. pollen grains - Reticulate type

\begin{tabular}{|c|c|c|c|c|c|c|c|c|c|c|}
\hline \multirow{2}{*}{ Species } & \multirow{2}{*}{ Size } & \multirow{2}{*}{ Shape } & \multirow{2}{*}{ Polarity } & \multicolumn{6}{|c|}{ Apertures } & \multirow{2}{*}{$\begin{array}{l}\text { Exine ornamentation } \\
\text { (LM and SEM) }\end{array}$} \\
\hline & & & & $n^{0}$ & type & endoaperture & ectoaperture & costa & fastigium & \\
\hline W. ackermanniana & M & OS & isopolar & (5)-6 & Colporus & $\begin{array}{l}\text { lalongate: } \\
\text { elliptical }\end{array}$ & $\begin{array}{c}\text { long, } \\
\text { narrow, } \\
\text { apices acute }\end{array}$ & - & - & $\begin{array}{l}\text { Reticulate-perforate; } \\
\text { homogeneous } \\
\text { and circular lumina; } \\
\text { semitectum } \\
\text { slightly undulating }\end{array}$ \\
\hline W. albicans & M & PS & isopolar & 3-(4) & Colporus & $\begin{array}{l}\text { lalongate: } \\
\text { elliptical }\end{array}$ & $\begin{array}{l}\text { short, } \\
\text { narrow, } \\
\text { apices } \\
\text { rounded }\end{array}$ & + & + & $\begin{array}{l}\text { Reticulate-perforate; } \\
\text { heterogeneous } \\
\text { and irregular lumina, } \\
\text { semitectum } \\
\text { slightly undulating }\end{array}$ \\
\hline W. brachypetala & M & OS & isopolar & $\begin{array}{l}\text { (3)-4- } \\
(5)\end{array}$ & Colporus & $\begin{array}{l}\text { lalongate: } \\
\text { elliptical }\end{array}$ & $\begin{array}{l}\text { long, broad, } \\
\text { apices } \\
\text { rounded }\end{array}$ & + & - & $\begin{array}{l}\text { Reticulate-perforate; } \\
\text { homogeneous } \\
\text { and irregular lumina; } \\
\text { semitectum } \\
\text { slightly undulating }\end{array}$ \\
\hline W. bracteosa & $\mathrm{L}$ & PS & isopolar & 3 & Colporus & lolongate & $\begin{array}{l}\text { narrow, } \\
\text { apices acute }\end{array}$ & + & - & $\begin{array}{l}\text { Reticulate-perforate; } \\
\text { homogeneous } \\
\text { and irregular lumina; } \\
\text { semitectum } \\
\text { undulating }\end{array}$ \\
\hline W. cinerascens & M & OS & isopolar & $\begin{array}{l}(5)-6- \\
(7)\end{array}$ & Colporus & $\begin{array}{l}\text { lalongate: } \\
\text { elliptical }\end{array}$ & $\begin{array}{c}\text { long, } \\
\text { narrow, } \\
\text { apices acute }\end{array}$ & + & + & $\begin{array}{c}\text { Reticulate; } \\
\text { heterogeneous } \\
\text { and irregular } \\
\text { lumina; semitectum } \\
\text { undulating }\end{array}$ \\
\hline W. communis & M to $\mathrm{L}$ & S & apolar & $\begin{array}{c}9-10- \\
11-12- \\
(13-14)\end{array}$ & Colporus & circular & $\begin{array}{l}\text { broad, apices } \\
\text { rounded }\end{array}$ & - & - & $\begin{array}{l}\text { Reticulate-perforate; } \\
\text { heterogeneous } \\
\text { and irregular lumina; } \\
\text { semitectum } \\
\text { undulating }\end{array}$ \\
\hline W. coriacea & M & OS & isopolar & 4 & Colporus & $\begin{array}{l}\text { lalongate: } \\
\text { elliptical }\end{array}$ & $\begin{array}{l}\text { short, } \\
\text { narrow, } \\
\text { apices acute }\end{array}$ & + & + & $\begin{array}{l}\text { Reticulate-perforate; } \\
\text { heterogeneous } \\
\text { and circular lumina; } \\
\text { semitectum } \\
\text { non-undulating }\end{array}$ \\
\hline W. macropoda & M to $\mathrm{L}$ & PS & isopolar & (3) -4 & Colporus & $\begin{array}{l}\text { lalongate: } \\
\text { elliptical }\end{array}$ & $\begin{array}{l}\text { short, broad, } \\
\text { apices acute }\end{array}$ & + & - & $\begin{array}{l}\text { Reticulate-perforate; } \\
\text { heterogeneous and } \\
\text { irregular } \\
\text { lumina; semitectum } \\
\text { slightly } \\
\text { undulating }\end{array}$ \\
\hline W. operculata & $\mathrm{M}$ to $\mathrm{L}$ & OS-PS & isopolar & $\begin{array}{l}(3-4)-5- \\
(6)\end{array}$ & Colporus & $\begin{array}{l}\text { lalongate: } \\
\text { rectangular a } \\
\text { elliptical }\end{array}$ & $\begin{array}{l}\text { short to } \\
\text { long, narrow } \\
\text { to broad; } \\
\text { apices acute }\end{array}$ & - & + & $\begin{array}{c}\text { Reticulate; } \\
\text { heterogeneous and } \\
\text { irregular } \\
\text { lumina; semitectum } \\
\text { undulating }\end{array}$ \\
\hline W. rotundifolia & M & S & apolar & $\begin{array}{l}(10)-12- \\
13-(14)\end{array}$ & Colporus & circular & $\begin{array}{l}\text { narrow, } \\
\text { apices } \\
\text { rounded }\end{array}$ & - & - & $\begin{array}{l}\text { Reticulate-perforate; } \\
\text { heterogeneous and } \\
\text { irregular } \\
\text { lumina; semitectum } \\
\text { undulating }\end{array}$ \\
\hline W. viscosissima & M & OS & isopolar & 3 & Colporus & $\begin{array}{l}\text { Lalongate: } \\
\text { elliptical }\end{array}$ & $\begin{array}{l}\text { short, } \\
\text { narrow, } \\
\text { apices } \\
\text { rounded }\end{array}$ & - & + & $\begin{array}{l}\text { Reticulate; } \\
\text { heterogeneous and } \\
\text { irregular lumina; } \\
\text { semitectum } \\
\text { undulating }\end{array}$ \\
\hline
\end{tabular}

Note: L=large; $\mathrm{M}=$ medium; OS=oblate spheroidal; $\mathrm{PS}=$ prolate spheroidal; $S=$ spheroidal; $[+]$ present; [-] absent 
Table 2. Morphological characteristics of Waltheria L. pollen grains - Echinate type

\begin{tabular}{|c|c|c|c|c|c|c|c|c|c|c|}
\hline \multirow{2}{*}{ Species } & \multirow{2}{*}{ Size } & \multirow{2}{*}{ Shape } & \multirow{2}{*}{ Polarity } & \multicolumn{6}{|c|}{ Apertures } & \multirow{2}{*}{$\begin{array}{l}\text { Exine ornamentation } \\
\text { (LM and SEM) }\end{array}$} \\
\hline & & & & $n^{0}$ & type & endoaperture & ectoaperture & costa & fastigium & \\
\hline W. ackermanniana & $\mathrm{L}$ & OS & isopolar & (5)-6-7 & Colporus & circular & $\begin{array}{l}\text { long, } \\
\text { narrow, } \\
\text { apices acute }\end{array}$ & + & - & $\begin{array}{c}\text { Echinate-rugulate- } \\
\text { perforate; echinae densely } \\
\text { distributed; }\end{array}$ \\
\hline W. albicans & M & OS & isopolar & $\begin{array}{l}(4)-5- \\
(6)\end{array}$ & Colporus & circular & $\begin{array}{l}\text { short, } \\
\text { narrow, } \\
\text { apices acute }\end{array}$ & - & - & $\begin{array}{l}\text { Echinate-perforate; } \\
\text { echinae densely } \\
\text { distributed; }\end{array}$ \\
\hline W. brachypetala & M to $\mathrm{L}$ & OS & isopolar & $4-5-(6)$ & Colporus & $\begin{array}{l}\text { lalongate: } \\
\text { elliptical }\end{array}$ & $\begin{array}{l}\text { short, } \\
\text { narrow, } \\
\text { apices acute }\end{array}$ & + & - & $\begin{array}{l}\text { Echinate-rugulate- } \\
\text { perforate; echinae } \\
\text { sparsely distributed; }\end{array}$ \\
\hline W. bracteosa & $\mathrm{L}$ & Os & isopolar & $6-(7)$ & Colporus & circular & $\begin{array}{l}\text { long, broad, } \\
\text { apices acute }\end{array}$ & + & - & $\begin{array}{c}\text { Echinate-microreticulate; } \\
\text { echinae densely } \\
\text { distributed; }\end{array}$ \\
\hline W. cinerascens & L & SO-OS & isopolar & (5)-6-7 & Colporus & $\begin{array}{l}\text { lalongate: } \\
\text { rectangular }\end{array}$ & $\begin{array}{l}\text { long, } \\
\text { narrow, } \\
\text { apices acute }\end{array}$ & + & + & $\begin{array}{c}\text { Echinate-rugulate- } \\
\text { perforate; echinae densely } \\
\text { distributed; }\end{array}$ \\
\hline W. communis & $\mathrm{L}$ & S & apolar & $\begin{array}{c}10- \\
(11)- \\
12-13- \\
14\end{array}$ & Porus & circular & circular & - & - & $\begin{array}{l}\text { Echinate-perforate; } \\
\text { echinae densely } \\
\text { distributed; }\end{array}$ \\
\hline W. coriacea & $\mathrm{L}$ & OS & isopolar & $4-5-(6)$ & Colporus & $\begin{array}{l}\text { lalongate, } \\
\text { elliptical to } \\
\text { circular }\end{array}$ & $\begin{array}{l}\text { very short, } \\
\text { broad, } \\
\text { apices } \\
\text { acute }\end{array}$ & + & - & $\begin{array}{c}\text { Echinate-rugulate- } \\
\text { perforate; echinae densely } \\
\text { distributed; }\end{array}$ \\
\hline W. excelsa & $\mathrm{L}$ & SO & isopolar & (5) -6 & Colporus & $\begin{array}{l}\text { lalongate: } \\
\text { rectangular } \\
\text { to } \\
\text { elliptical }\end{array}$ & $\begin{array}{l}\text { long, broad; } \\
\text { apices } \\
\text { rounded }\end{array}$ & - & - & $\begin{array}{l}\text { Echinate-perforate- } \\
\text { granulate; echinae } \\
\text { sparsely distributed; }\end{array}$ \\
\hline W. macropoda & $\mathrm{L}$ & OS & isopolar & $\begin{array}{l}(5)-6- \\
7- \\
(8)\end{array}$ & Colporus & lolongate & $\begin{array}{l}\text { long; apices } \\
\text { acute }\end{array}$ & - & - & $\begin{array}{c}\text { Echinate-micoreticulate; } \\
\text { echinae densely } \\
\text { distributed; }\end{array}$ \\
\hline W. rotundifolia & $\mathrm{L}$ & $S$ & apolar & $\begin{array}{c}(10)- \\
12- \\
13-(14)\end{array}$ & Colporus & lolongate & $\begin{array}{c}\text { narrow; } \\
\text { apices acute }\end{array}$ & - & - & $\begin{array}{c}\text { Echinate-rugulate- } \\
\text { perforate; echinae densely } \\
\text { distributed; }\end{array}$ \\
\hline W. selloana & M to $\mathrm{L}$ & OS & isopolar & $\begin{array}{l}\text { (5)-6- } \\
(7)\end{array}$ & Colporus & circular & $\begin{array}{l}\text { short to } \\
\text { long, } \\
\text { narrow; } \\
\text { apices acute }\end{array}$ & + & - & $\begin{array}{l}\text { Echinate-perforate; } \\
\text { echinae densely } \\
\text { distributed; }\end{array}$ \\
\hline W. vernonioides & $\mathrm{L}$ & S & apolar & $\begin{array}{c}12-13- \\
14-15- \\
(16)\end{array}$ & Porus & circular & $\begin{array}{l}\text { broad; } \\
\text { apices } \\
\text { rouded }\end{array}$ & - & - & $\begin{array}{l}\text { Echinate-perforate; } \\
\text { echinae densely } \\
\text { distributed; }\end{array}$ \\
\hline W. viscosissima & $\mathrm{L}$ & OS & isopolar & (5)-6 & Colporus & $\begin{array}{l}\text { lalongate: } \\
\text { elliptical }\end{array}$ & $\begin{array}{l}\text { short; } \\
\text { apices acute }\end{array}$ & + & - & $\begin{array}{c}\text { Echinate-microreticulate; } \\
\text { echinae densely } \\
\text { distributed; }\end{array}$ \\
\hline
\end{tabular}

Note: $\mathrm{L}=$ large; $\mathrm{M}=$ medium; $\mathrm{OS}=$ oblate spheroidal; $\mathrm{SO}=$ suboblate; $\mathrm{S}=$ spheroidal; $[+]$ present; [-] absent

similar results, whereas Saba et al. (2004) and Saba (2007) found no such correlation. In this study, no significant difference in thickness was observed between the floral morphs of $W$. bracteosa and $W$. coriacea.

Among the reticulate pollen grains, the sexine type was almost always thicker than the nexine, while the reverse was true among the echinate type. However, most authors noted this "rule" only among longistylous morphs (Erdtman 1952;
Melhem et al. 1976; Saba \& Santos 2003; 2015; Saba et al. 2004).

This study was the second time that the ultrastructure of Waltheria pollen grains has been investigated. Saba \& Santos (2015) observed four levels of sexine stratification: Sexine 1 corresponding to the compact continuous foot layer, sexine 2 formed by thicker columellae, sexine 3 is defined as the tectum, which is thinner, and sexine 4 was formed by muriform thickening on sexine 3 , which gives 


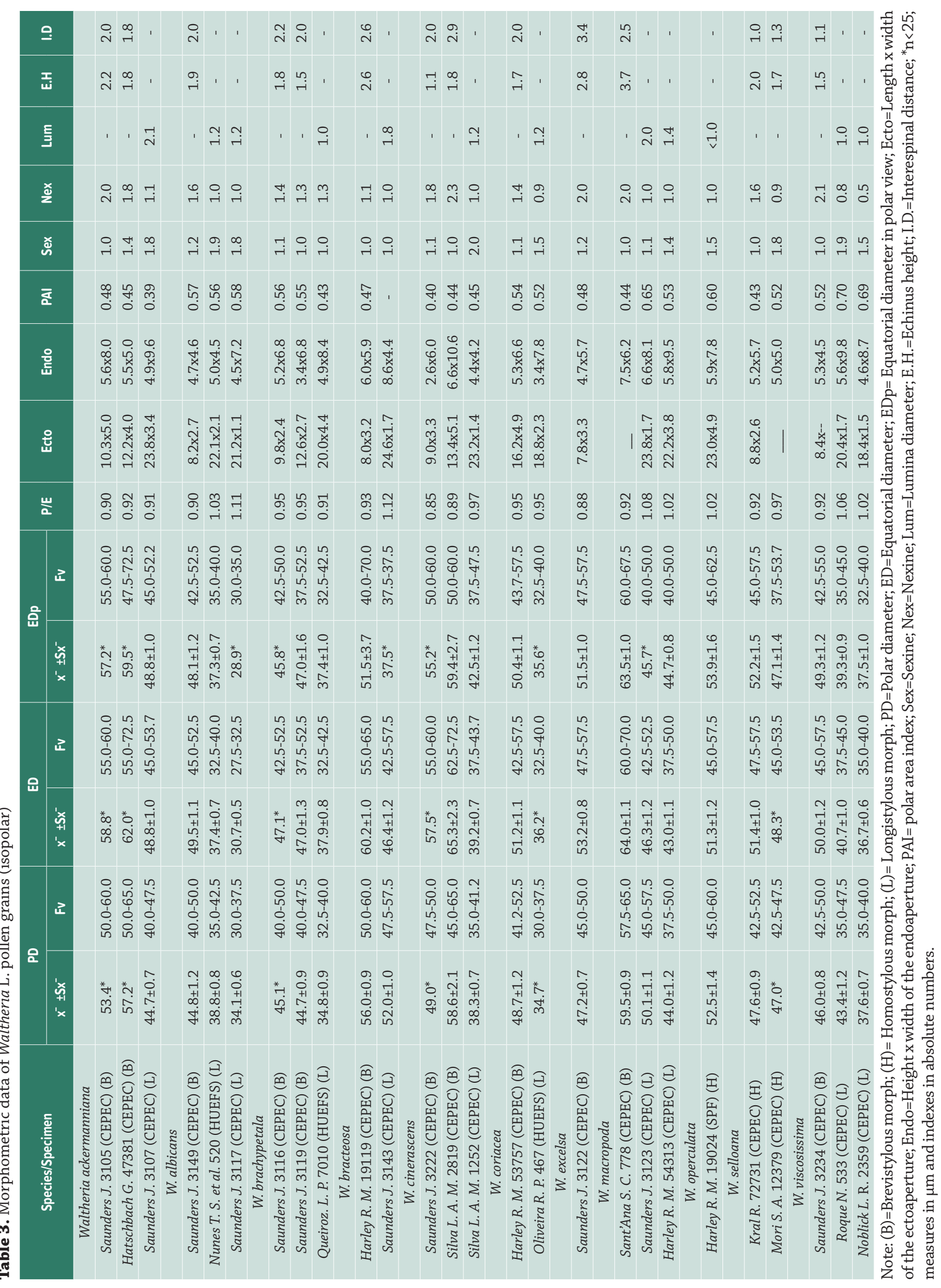


Table 4. Morphometric data of Waltheria L. pollen grains (apolar)

\begin{tabular}{|c|c|c|c|c|c|c|c|c|c|c|}
\hline \multirow{2}{*}{ Species/Specimen } & \multicolumn{2}{|c|}{ D } & \multirow{2}{*}{ P/E } & \multirow{2}{*}{ Ecto } & \multirow{2}{*}{ Endo } & \multirow{2}{*}{ Sex } & \multirow{2}{*}{ Nex } & \multirow{2}{*}{ Lum } & \multirow{2}{*}{ E.H. } & \multirow{2}{*}{ I.D } \\
\hline & $\bar{z}+S_{\bar{x}}$ & Fv & & & & & & & & \\
\hline \multicolumn{11}{|l|}{ W. communis } \\
\hline Saunders J. 3227 (CEPEC) (B) & $58.5 \pm 1.0$ & $52.5-62.5$ & 1.00 & $7.5 \times 4.0$ & $4.7 \times 4.9$ & 1.0 & 2.0 & - & 1.8 & 2.5 \\
\hline Giulietti. A. M. 2455 (HUEFS) (B) & $55.7 \pm 1.2$ & $50.0-62.5$ & 1.00 & - & $5.3 \times 4.9$ & 1.3 & 2.3 & - & 2.1 & 1.9 \\
\hline Saunders J. 3229 (CEPEC) (L) & $52.7 \pm 1.8$ & $45.0-65.0$ & 1.00 & $6.1 \times 3.0$ & $5.6 \times 5.2$ & 1.5 & 1.1 & 4.2 & - & - \\
\hline \multicolumn{11}{|l|}{ W. rotundifolia } \\
\hline Gonçalves L. M. C. 76 (CEPEC) (B) & $55.9 \pm 1.0$ & $50.0-60.0$ & 1.00 & $5.5 \times 1.7$ & $5.1 \times 4.4$ & 1.0 & 1.8 & - & 2.1 & 1.7 \\
\hline Saunders J. 3126 (CEPEC) (L) & $49.8 \pm 0.7$ & $47.5-52.5$ & 1.00 & $6.4 \times 1.5$ & $4.7 \times 4.6$ & 2.8 & 0.9 & 3.8 & - & - \\
\hline \multicolumn{11}{|l|}{ W. vernonioides } \\
\hline Saunders J. 3060 (CEPEC) (H) & $55.4 \pm 1.4$ & $47.5-60.0$ & 1.00 & $5.7 \times 3.0$ & $4.7 \times 4.5$ & 1.0 & 2.3 & - & 1.5 & 1.0 \\
\hline Hoehne E. C. 2976 (SP) (H) & $54.8 \pm 1.2$ & $50.0-60.0$ & 1.00 & $7.0 \times 4.3$ & $4.6 \times 4.6$ & 2.8 & 2.8 & - & 1.4 & 1.0 \\
\hline
\end{tabular}

Note: $(B)=$ Brevistylous morph; $(\mathrm{H})=$ Homostylous morph; $(\mathrm{L})=$ Longistylous morph; $\mathrm{D}=$ Polen grains diameter; Ecto= Length $\mathrm{x}$ width of the ectoaperture; Endo= Height $\mathrm{x}$ width of the endoaperture; Sex= sexine; Nex= nexine; Lum= Lumina diameter; E.H.= Echinus heigh; D.I= Interespinal distance; ${ }^{*} \mathrm{n}<25$; measures in $\mu \mathrm{m}$ and indexes in absolute numbers.

the undulating appearance to the tectum. Of the species studied here, only $W$. operculata did not have the fourth layer, despite its undulating appearance under LM.

Most authors who have studied Waltheria pollen grains determined that the exine ornamentation is microreticulate, reticulate, or suprareticulate among longistylous morphs (Erdtman 1952; Köhler 1971; Melhem et al. 1976; Miranda \& Andrade 1989; Saunders 1993; Saba \& Santos 2000; Saunders 2005). Here we clearly observed perforations located on the lumina under SEM. This type of ornamentation was interpreted as reticulate-perforated in this study.

As in the present study, Köhler (1971) was unable to clearly observe perforations on the tectum of brevistylous pollen grains under LM. Köhler (1976) confirmed the existence of a semitectum using SEM and reported undulations and perforations distributed densely over the surface. While the specimens studied by Saba et al. (2004) showed pollen grains with microreticulate semitectum, demonstrating that these perforations are difficult to detect under LM.

\section{Conclusion}

A high degree of pollen heteromorphism due to heterostyly was confirmed in Waltheria, which is frequently detected by palynologists (Saba et al. 2004; Saba \& Santos 2015).

The apertural type and number and their distribution throughout the pollen grains were important factors for grouping the species, and exine ornamentation could not be used to differentiate species, although it was useful to precisely distinguish the pollen grains of brevistylous and longistylous morphs.

A better understanding of the pollen ultrastructure of Waltheria was achieved through this study, as the data obtained here are presented for the first time for most of these species.

The palynological characterization of the species studied here provide essential data for future taxonomic and/or phylogenetic studies on the genus Waltheria, as well as other applied research among its species. However, further studies are necessary for a complete palynological characterization and, consequently, a more concise definition of the taxa, which will require that a larger sample size be investigated under SEM and TEM.

\section{Acknowledgements}

The authors would like to thank CAPES (Coordenadoria de Aperfeiçoamento de Pessoal de Nível Superior) for the financial support granted to the first author, and FIOCRUZ, for making our SEM and TEM studies possible.

\section{References}

Borges RLB. 2008. Morfologia polínica de Eriocaulaceae e suas implicações taxonômicas. MSc Thesis, Universidade Estadual de Feira de Santana, Feira de Santana.

Darwin C. 1877. The different forms of flowers on plants of the same species. London, John Murray.

Dessein S, Huysmans S, Robbrecht E, Smets E. 2002. Pollen of African Spermacoce species (Rubiaceae). Grana 41: 69-89.

Dessein S, Ochoterena H, Block P, et al. 2005. Palynological characters and their phylogenetic signal in Rubiaceae. The Botanical Review 71: 354-414.

Erdtman G. 1952. Pollen morphology and plant taxonomy: angiosperms. Stockholm, Almqvist and Wiksell.

Erdtman G. 1960. The acetolysis method: A revised description. Svensk Botanisk Tidskrift. 54: 561-564.

Esteves G. 2015. Waltheria in Lista de Espécies da Flora do Brasil. Rio de Janeiro, Jardim Botânico do Rio de Janeiro. http://floradobrasil.jbrj. gov.br/2012/FB009270. 10 Mar. 2017.

Ganders FR, 1979. The biology of heterostyly. New Zealand Journal of Botany 17: 607-635.

Hesse M, Halbritter H, Zetter R, et al. 2009. Pollen terminology: An illustrated handbook. New York, Springer Wein.

Köhler E. 1971. Zur pollenmorphologie der gattung Waltheria L. (Sterculiaceae). Feddes Repertorium 82: 125-153.

Köhler E. 1973. Über einen bemerkenswerten pollendimorphismus in der gattung Waltheria L. Grana 13: 57-64. 


\section{Cristiano Eduardo Amaral Silveira Júnior, Luciene Cristina Lima e Lima and Marileide Dias Saba}

Köhler E. 1976. Pollen dimorphism and heterostyly in the genus Waltheria L. (Sterculiaceae). In: Ferguson IK, Müller J. (eds.) The evolutionary significance of the exine. London, Journal of the Linnean Society 1: 147-161.

Melhem TS, Silvestre MSF, Lucas NMC. 1976. Pollen morphological studies in Sterculiaceae. Hoehnea 6: 23-32.

Miranda MMB, Andrade TAP, 1989. Pólen das plantas do Nordeste Setentrional do Brasil III. Sterculiaceae. Acta Botanica Brasilica 3: 281-292.

Miranda MMB, Andrade TAP, Alves MH. 1992. Pólen das plantas do nordeste setentrional do Brasil IV - Stercullaceae, Byttneria Murs e Melochia Linn. Ciência Agronômica, Fortaleza 23: 85-91.

Palacios-Chávez R, Arreguin SML, Quiroz DL, 1990. Morfologia de los granos de polen de la familia Sterculiaceae de la Estacion de Biologia Chamela, Jalisco. Palynologica et Palaeobotánica 2: 62-81.

Punt W, Hoen PP, Blackmore S, Nilson S, Le Thomas A. 2007. Glossary of pollen and spore terminology. Review of Palaeobotany and Palynology 143: 1-81.

Roubik DW, Moreno PJE. 1991. Pollen and spores of Barro Colorado Island. Monographs in Systematic Botany from the Missouri Botanical Garden 36: 1-270.

Saba MD. 2007. Morfologia polínica de Malvaceae: Implicações taxonômicas e filogenéticas. $\mathrm{PhD}$ thesis, Universidade Estadual de Feira de Santana, Feira de Santana.

Saba MD, Santos FAR. 2000. Morfologia polínica de espécies de Sterculiaceae do Pico das Almas (Bahia- Brasil). Revista Universidade de Guarulhos - Geociências. (especial): 201-204.
Saba MD, Santos FAR. 2003. Morfologia polínica de Sterculiaceae das dunas do Abaeté, Salvador - Bahia. Sitientibus 3: 109-114.

Saba MD, Santos FAR. 2015. Pollen morphology and exine ultrastructure of selected species of Waltheria L. (Byttnerioideae-Malvaceae). Review of Palaeobotany and Palynology 221: 204-210.

Saba MD, Santos FAR, Esteves GL. 2004. Palinotaxonomia das tribos Byttnerieae DC., Hermannieae DC. e Helictereae DC. (Malvaceae s.l.) da flora da Bahia, Brasil. Hoehnea 31: 189-214.

Saunders JG. 1993. Four new distylous species of Waltheria (Sterculiaceae) and a key to the Mexican and Central American species and species groups. Systematic Botany 18: 356-376.

Saunders JG. 1995. Systematics and evolution of Waltheria (SterculiaceaeHermannieae) PhD Thesis, The University of Texas, Austin.

Saunders JG. 2005. New species of Waltheria (Hermannieae, Byttnerioideae, Malvaceae) from Paraguay, Argentina, and Venezuela, and two new records for Paraguay. Darwiniana 43: 201-211.

Schumann C. 1886. Sterculiaceae. In: Martius CFP, Eicheler AG, Urban I. (eds.) Flora Brasiliensis. Vol. XII. Part III. Oldenburg, Monachii.

Sharma BD. 1970. Studies of Indian pollen grains in relation to plant taxonomy - Sterculiaceae. Proceedings of the National Academy of Sciences, India Section B 35: 320-359.

Silveira-Júnior, CEA, Lima, LLC, Saba, MD. 2015. Palynological study of heterostylous species of Melochia L. (Byttinerioideae-Malvaceae) occurring in Bahia, Brazil. Review of Palaeobotany and Palynology 221: 192-203.

Thiers B. 2014. [continuously updated]. Index Herbariorum: A global directory of public herbaria and associated staff. New York, New York Botanical Garden's Virtual Herbarium. http://sweetgum.nybg.org/ih/ 